\title{
IMPLICATIONS OF CORONAVIRUS DISEASE-19 ON CLINICAL CLERKSHIP AND HOSPITAL POSTINGS
}

\author{
BUSAYO ADETUNJI*
}

Ladoke Akintola University of Technology, Ogbomosho, Oyo State, Nigeria. Email: henrybusayo04@gmail.com

Received: 7 Sep 2020, Revised and Accepted: 10 Jan 2021

\section{ABSTRACT}

The coronavirus pandemic hit the world sweeping through all parts of the world, crumbling economies, and overwhelming health systems. Undergraduate medical education has been totally disrupted and put to a stop. As Nigeria braces to open on medical schools and clinical rotation about to begin, the palpable panic that accompanies patients-students spread of the virus will definitely affect undergraduate medical education in Nigeria. At present, little is known in Nigeria about the long-term effects of Coronavirus disease-19 on clinical clerkship and undergraduate medical education and adaptations to juxtapose future pandemics with medical education. This review accesses risks, plans, and policies in place and how they will affect undergraduate medical education.

Keywords: Coronavirus disease-19, Clinical clerkship, Undergraduate medical education, Clinical rotations, Severe acute respiratory syndrome coronavirus 2 .

(C) 2021 The Authors. Published by Innovare Academic Sciences Pvt Ltd. This is an open access article under the CC BY license (http://creativecommons org/licenses/by/4.0/) DOI: http://dx.doi.org/10.22159/ijms.2021v9i5.39666. Journal homepage: https://innovareacademics.in/journals/index.php/ijms

\section{INTRODUCTION AND BACKGROUND}

The Coronavirus disease (COVID-19) is an infectious disease caused by the novel Coronavirus Severe Acute Respiratory Syndrome Coronavirus 2 (SARS-CoV-2) [1,2]. COVID-19 was first discovered in China in December 2019 and the first case confirmed in Nigeria announced in February 2020 [2,3]

The rapid spread of the virus and its declaration as a Public Health Emergency of International Concern by the World Health Organization (WHO) [1] has caused countries to fold up businesses, schools, markets, places of worship, and all forms of public gatherings. Among the various economic [4] and social impacts of COVID-19, medical schools have been shut down and education put to halt around the world [5].

This review aims to put side by side the impact of SARS-CoV2 on the fate of medical students and how it might affect hands-on practical training and clinical clerkship.

\section{REVIEW}

In Nigeria, undergraduate medical education is divided into two parts: a pre-clinical part and a clinical part comprising various levels of professional examinations [6]. Undergraduate medical students spend the first 3 years of their education in the pre-clinical school and the last 3 years in clinical school. In clinical school, students begin hospital rotations gaining exposure to clinical practice and methodology [7]. Undergraduate medical education in Nigeria involves series of didactic lectures, tutorials, seminars, presentations, small group discussions, and clinical postings. The major part of learning for medical students takes place in the hospital; here students get instructional teaching and guided learning.

At the wake of COVID-19 and attempts to curb its spreads among students, the National Universities Commission initially ordered the closure of Nigeria universities for 1 month beginning from March 23,2020 , but this has since been extended months after months [8].

While clinical clerkship has been canceled or suspended in some countries around the world [9]. No news about the cancelation/ suspension of hospital rotations has been announced in Nigeria yet but there are debates and concerns about whether adequate measures are in place to protect medical students against the virus.

Student-Patient contact will be affected drastically in an attempt to curtail the spread of Coronavirus. Participation of students inpatient healthcare might be affected and invariably learning impeded. Clinical exposure is a crucial part of medical learning and COVID-19 might reduce access to this exposure. Teachings inwards, accident and emergency units and clinics might be eliminated in many medical schools with high cases of SARS-CoV2. The fear of the virus might also affect the composure and willingness of medical students to participate in patient care.

Recent articles on the effect of COVID-19 on the mental health of students have also shown that the virus has caused an increase in the academic stressors on students [10]. The widespread fear and uncertainty of the virus are likely to increase the burden on students making learning uncomfortable. These suggest that the COVID-19 pandemic may have continuing implications on the academic performance, careers, and competence of many medical students. Many students have been out of school for a long time and this is also likely to have effect on their academic performance.

The economic impact of COVID-19 is also a tale to tell. Many countries are at the brink of recession and inflation rates skyrocketing [11]. It is similarly likely that this might cause a financial and mental health burden on students affecting their academic performance.

As medical education requires physical hands-on training, the option of embracing technology and switching to online teachings might be a far call.

\section{CONCLUSION}

As medical schools prepare to open up, clinical clerkship and hospital rotation would be hit greatly. The Nigerian University Commission and Medical and Dental Council of Nigeria the governing councils of medical education in Nigeria has not put forth any guideline outlining the fate of medical students in the face of this pandemic.

COVID-19 has the potential to sub-acutely affect medical education in Nigeria if timely intervention and policies are not put in place. 


\section{RECOMMENDATION}

1. Provision of free or subsidized Personal Protective Equipments for students.

2. A review of undergraduate medical education policies in the situations of global public health challenges.

\section{LIMITATION TO THE STUDY}

There is little information on guidelines for medical schools in Nigeria in the post-COVID-19 era.

\section{CONFLICT OF INTEREST}

The author declared no potential conflicts of interest with respect to the research, authorship, and/or publication of this article.

\section{FUNDING}

The author(s) received no financial support for the research, authorship, and/or publication of this article.

\section{REFERENCES}

1. World Health Organization. Coronavirus. Available from: https://www.who. int/health-topics/coronavirus\#tab=tab_1. [Last accessed on 2020 Sep 05].

2. World Health Organization. Coronavirus Disease (COVID-19)
Pandemic. Available form: https://www.who.int/emergencies/diseases/ novel-coronavirus-2019. [Last accessed on 2020 Sep 05].

3. First Case of Corona Virus Disease Confirmed in Nigeria. Available from: https:/www.ncdc.gov.ng/news/227/first-case-of-corona-virusdisease-confirmed-in-nigeria. [Last accessed on 2020 Sep 05].

4. Anoushiravani AA, O'Connor CM, DiCaprio MR, Iorio R. Economic impacts of the COVID-19 crisis: An orthopaedic perspective. J Bone Joint Surg Am 2020;102:937-41.

5. Clark J. Fear of SARS thwarts medical education in Toronto. BMJ 2003;326:784.

6. Ibrahim M. Medical education in Nigeria. Med Teach 2007;29:901-5.

7. Wijnen-Meijer M, Burdick W, Alofs L, Burgers C, Cate O. Stages and transitions in medical education around the world: Clarifying structures and terminology. Med Teach 2013;35:301-7.

8. Azeezat A. Coronavirus: NUC Announces Closure of Nigerian Universities. Available from: https://www.premiumtimesng.com/news/ headlines/382880-coronavirus-nuc-announces-closure-of-nigerianuniversities.html. [Last accessed on 2020 Sep 05].

9. Akers A, Blough C, Iyer MS. COVID-19 implications on clinical clerkships and the residency application process for medical students. Cureus 2020;12:e7800.

10. Grubic N, Badovinac S, Johri AM. Student mental health in the mids of the COVID-19 pandemic: A call for further research and immediate solutions. Letter 2020;???:???.

11. UNDP COVID-19 Socio-economic Impact. Available from: https:// www.undp.org/content/undp/en/home/coronavirus/socio-economicimpact-of-covid-19.html. [Last accessed on 2020 Sep 05]. 